\title{
ФАКТОРИ ПСИХІЧНОЇ ТРАВМАТИЗАЦІЇ У ВНУТРІШНЬО ПЕРЕМІЩЕНИХ ОСІБ: ÏХ СТРУКТУРА ТА ДИНАМІКА У ЧАСІ
}

\author{
○Н. О. Марута, Т. В. Панько, Г. Ю. Каленська, С. П. Колядко, І. О. Явдак, С. О. Волкова \\ ДУ «Інститут неврології, психіатрії та наркології НАМн України»
}

PЕзЮмЕ. Сьогодні Україна займає дев'яте місце у світі за кількістю внутрішньо переміщених осіб (ВПО). Масштабні вимушені внутрішні міграції останніх років не могли не відобразитися на стані здоров'я як певної соціальної групи, так і на стані здоров'я населення у цілому.

Мета - вивчення факторів психічної травматизації, їх динаміки у часі та впливу на стан психічного здоров'я, визначення стресостійкості та соціальної адаптації у ВПО.

Матеріал і методи. Методи обстеження включали клініко-психопатологічний з оцінкою факторів психічної травматизації, методику визначення стресостійкості та соціальної адаптації Т. Холмса і Р. Раге для оцінки актуального рівня стресу протягом останнього року, статистичні методи.

Дослідження проведено в ДУ «Інститут неврології, психіатрії та наркології НАМН України» у відділі пограничної психіатрії. Всього було обстежено 213 ВПО. Усі обстежені були поділені на 3 групи: до І групи увійшли 94 ВПО із загальної популяції, у яких не було виявлено психічних розладів (умовно здорові); 68 осіб, у яких були визначені окремі психічні симптоми, що не сягали клінічного рівня, склали II групу (група ризику) та 51 особа, що звернулася за медичною допомогою та мала діагностовані психічні розлади, увійшли до III групи (обстежені з психічними розладами).

Результати. Всім обстеженим була проведена оцінка стресогенних факторів (СФ), що включали фізіологічні, психоемоційні, соціально-психологічні та інформаційні чинники та відображала їх динаміку в часі. Рівень опірності стресу відрізнявся у здорових, хворих та осіб з групи ризику.

Висновки. Загальна оцінка впливу стресогенних чинників на ВПО свідчить про їх поєднану дію, різний ступінь патогенності та динаміки у часі.

КлючовІ СлОВА: фактори психічної травматизації; внутрішньо переміщені особи.

Вступ. Глобальні світові процеси, військовополітичні зіткнення, етнічні конфлікти, кризи в економічній системі держав за останні десятиріччя посилили зростання числа вимушених переселенців і біженців, спровокували істотні трансформації у світогляді та душевному стані людей, змінили їх спосіб мислення та соціальну поведінку в зв'язку із вимушеним переміщенням та зміною місця проживання. Вимушена міграція входить до числа складних життєвих ситуацій, вона вимагає від людини зусиль, що перебувають на межі адаптивних можливостей або навіть перевершують наявні резерви. Ії̈, без сумніву, можна віднести до числа екстремальних подій, коли перед особистістю постає необхідність подолання надскладних життєвих обставин, рівноцінних проблемі виживання. Сьогодні Україна займає дев'яте місце у світі за кількістю внутрішньо переміщених осіб (ВПО). Масштабні вимушені внутрішні міграції останніх років не могли не відобразиися на стані здоров'я як певної соціальної групи, так і всього населення загалом [1-4].

В основі причин, що призводять до вимушеного переселення, лежить «екстремальний стрес» - коли перед людиною постає проблема боротьби з надскладними життєвими обставинами, що знаходяться на межі її адаптивних можливостей. При цьому саме висока інтенсивність від- чуття небезпеки, загрози для життя людини, визначають виражене прагнення подолати труднощі, що виникли. Вимушене переселення призводить до різкого зниження соціально-економічного статусу, труднощів адаптації, серйозних проблем у стосунках із місцевим населенням, що стає предиктором порушень психічного здоров'я ВПО $[2,3]$.

Процес адаптації ВПО супроводжується тривалим перенапруженням особистісних ресурсів, зривом захисно-пристосувальних механізмів і формуванням пограничних нервово-психічних розладів. Порушення психічного здоров'я на тлі численних психологічних і соціальних проблем призводять до трансформації особистісного реагування та дезадаптації. Українські вчені на основі системного підходу узагальнили основні проблеми переселенців із зони збройного конфлікту в східних регіонах. До них належать наступні:

- відсутність тимчасового і постійного житла;

- незабезпеченість роботою;

- відсутність грошової матеріальної допомо-

ги найуразливішим групам населення;

- відсутність соціального забезпечення;

- відсутність можливості повернення до місць попереднього проживання [5-8].

Зазначені проблемні питання $\epsilon$ об'єктивними чинниками вторинної травматизації вимушених 
Огляди літератури, оригінальні дослідження, погляд на проблему, випадок з практики, короткі повідомлення переселенців, що ускладнюють процес переживання психотравмуючих ситуацій та станів.

Для ВПО характерний високий рівень фрустрації базових та більш значущих потреб, а також висока міра розбіжності між очікуваннями і реальною ситуацією. Взаємодія людини з соціальним оточенням виявляє приховану схильність до розвитку психічних розладів [7-8].

Перешкоди, що виникають у житті ВПО, у вигляді соціальної дезадаптації, втрати на невизначений час звичного соціального статусу й упевненості в завтрашньому дні, пов'язані зі зміною місця проживання, відображаються на самооцінці переселенців, стосунках усередині сім'ї. Основні проблеми, що виникають перед переселенцями, концентруються на рівні працевлаштування (психогенний чинник - безробіття, матеріальна нестабільність), взаємодії з соціальним оточенням (ізоляція, конфлікти, на рівні особистісного реагування), проблеми самотності, втрати особиснісної ідентичності. Все перераховане вище впливає на загальне самопочуття, фізичне і психічне здоров'я переселенців, стає передумовою формування психогенних та психосоматичних захворювань, залежних від психоемоційної напруги, в якій з різною тривалістю перебуває особа, проходячи складний шлях адаптації на новому місці проживання [9-11].

Таким чином, існує ризик формування психічних порушень серед ВПО внаслідок внутрішнього переміщення, впливу комплексних психотравмуючих чинників, які призводять до суттєвих дистресових змін. Визначення чинників ризику розвитку психічних розладів у ВПО, їх специфіки, структури, впливу на особистісні особливості людини та формування клінічної картини психічних розладів $\epsilon$ актуальним питанням. Отримані результати дослідження створюють можливості для профілактики широкого спектра психопатології у вказаного контингенту населення.

Мета - вивчення факторів психічної травматизації, їх динаміки у часі та впливу на стан психічного здоров'я, визначення стресостійкості та соціальної адаптації у ВПО.

Матеріал і методи дослідження. Методи о6стеження включали клініко-психопатологічний з оцінкою факторів психічної травматизації, методику визначення стресостійкості та соціальної адаптації Т. Холмса і Р. Раге для оцінки актуального рівня стресу протягом останнього року [12] та статистичні методи.

Дослідження проводилось в ДУ «Інститут неврології, психіатрії та наркології НАМН України» у відділі пограничної психіатрії. Усього було обстежено 213 ВПО. Усі обстежені були поділені на 3 групи: до I групи увійшли 94 ВПО із загальної популяції, у яких не було виявлено психічних розладів (умовно здорові); 68 осіб, у яких були визначені окремі психічні симптоми, що не сягали клінічного рівня, склали II групу (група ризику) та 51 особа, що звернулася за медичною допомогою та мала діагностовані психічні розлади, увійшла в III групу (обстежені з психічними розладами).

У всіх обстежених була проведена оцінка стресогенних факторів (СФ), що включали фізіологічні, психоемоційні, соціально-психологічні та інформаційні чинники.

До фізіологічних чинників, які відзначалися переважно під час перебування в зоні військових дій, пацієнти відносили звуки стрілянини, вибухів, свист куль і осколків снарядів, необхідність постійно бути готовими бігти в укриття під час обстрілів, недостатній сон, відсутність повноцінного режиму їжі і пиття, відсутність звичних умов життя (перебої зі світлом, подачею газу, води).

Психоемоційні чинники включали відчуття реальної загрози для свого життя і життя близьких, страх бути вбитим, страх отримати поранення або травми, страх і тривогу перед кожною годиною життя в зоні військових дій, загибель оточуючих (військових і цивільних осіб), страх, що всі загрозливі події можуть повторитися.

Структура соціально-психологічних чинників включала нерозуміння того, що відбувається, нерозуміння причин бойових дій, відсутність контактів з родичами, які проживали в інших районах бойових дій, втрату соціального статусу - роботи, житла, розгубленість і неможливість змінити те, що відбувається й прийняття рішення, що робити далі.

В якості інформаційних чинників пацієнти відзначали відсутність правдивої інформації, їі суперечливість під час перебування в зоні випадкових подій та чинники «гібридної» війни під час перебування в мирній зоні.

Оцінка стресогенних чинників у ВПО І групи представлена у таблиці 1.

Наявність перерахованих стресогенних чинників оцінювалась у динаміці: ретроспективно під час перебування у зоні АТО, через 12 та 24 місяці після переїзду) та під час обстеження. Оцінка стресогенних чинників у обстежених ВПО I групи відображає певну їх динаміку. Всі обстежені констатували у себе наявність фізіологічних, психоемоційних, соціально-психологічних, інформаційних стресогенних чинників, що мали комплексний характер та пов'язувалися з пережитою військовою ситуацією, до якої ніхто з обстежених не був готовий.

Ретроспективна оцінка СФ під час перебування обстежених у зоні АТО свідчить, що у чоловіків переважали інформаційні та соціально-психологічні фактори $((95,24 \pm 3,29) \%$ та $(83,33 \pm 5,75)$ \% від- 
Огляди літератури, оригінальні дослідження, погляд на проблему, випадок з практики, короткі повідомлення Таблиця 1. Характеристика стресогенних чинників у обстежених внутрішньо переміщених осіб I групи (здорові)

\begin{tabular}{|c|c|c|c|c|c|c|c|c|c|}
\hline \multicolumn{2}{|c|}{ Стресогенний чинник } & \multicolumn{2}{|c|}{$\begin{array}{l}\text { Фізіологічний } \\
\text { чинник }\end{array}$} & \multicolumn{2}{|c|}{$\begin{array}{c}\text { Психоемоційний } \\
\text { чинник }\end{array}$} & \multicolumn{2}{|c|}{$\begin{array}{c}\text { Соціально-психологіч- } \\
\text { ний чинник }\end{array}$} & \multicolumn{2}{|c|}{$\begin{array}{c}\text { Інформаційний } \\
\text { чинник }\end{array}$} \\
\hline & & $\mathrm{n}$ & $\% \pm m$ \% & $\mathrm{n}$ & $\% \pm m \%$ & $\mathrm{n}$ & $\% \pm m$ \% & $\mathrm{n}$ & $\% \pm m$ \% \\
\hline \multirow{2}{*}{$\begin{array}{c}\text { Під час } \\
\text { перебування } \\
\text { в зоні АТО }\end{array}$} & $\begin{array}{c}\text { чоловіки } \\
(n=42)\end{array}$ & 32 & $76,19 \pm 6,57$ & 32 & $76,19 \pm 6,57$ & 35 & $83,33 \pm 5,75$ & 40 & $95,24 \pm 3,29$ \\
\hline & $\begin{array}{l}\text { жінки } \\
(n=52)\end{array}$ & 52 & $100,00 \pm 0,00$ & 52 & $100,00 \pm 0,00$ & 38 & $73,08 \pm 6,15$ & 28 & $53,85 \pm 6,91$ \\
\hline \multirow[t]{2}{*}{$\begin{array}{l}\text { Через } 12 \\
\text { місяців }\end{array}$} & $\begin{array}{l}\text { чоловіки } \\
(n=42)\end{array}$ & 21 & $50,00 \pm 7,72$ & 24 & $57,14 \pm 7,64$ & 32 & $76,19 \pm 6,57$ & 34 & $80,95 \pm 6,06$ \\
\hline & $\begin{array}{l}\text { жінки } \\
(n=52)\end{array}$ & 33 & $63,46 \pm 6,68$ & 38 & $73,08 \pm 6,15$ & 35 & $67,31 \pm 6,51$ & 19 & $36,54 \pm 6,68$ \\
\hline \multirow[t]{2}{*}{$\begin{array}{l}\text { Через } 24 \\
\text { місяці }\end{array}$} & $\begin{array}{l}\text { чоловіки } \\
(\mathrm{n}=42)\end{array}$ & 11 & $26,19 \pm 6,78$ & 17 & $40,48 \pm 7,57$ & 37 & $88,10 \pm 5,00$ & 21 & $50,00 \pm 7,72$ \\
\hline & $\begin{array}{l}\text { жінки } \\
(\mathrm{n}=52)\end{array}$ & 19 & $36,54 \pm 6,68$ & 41 & $78,85 \pm 5,66$ & 35 & $67,31 \pm 6,51$ & 10 & $19,23 \pm 5,47$ \\
\hline \multirow[t]{2}{*}{$\begin{array}{c}\text { Під час } \\
\text { обстеження }\end{array}$} & $\begin{array}{c}\text { чоловіки } \\
(\mathrm{n}=42)\end{array}$ & 7 & $16,67 \pm 5,75$ & 11 & $26,19 \pm 6,78$ & 11 & $26,19 \pm 6,78$ & 7 & $16,67 \pm 5,75$ \\
\hline & $\begin{array}{l}\text { жінки } \\
(n=52)\end{array}$ & 12 & $23,08 \pm 5,84$ & 19 & $36,54 \pm 6,68$ & 12 & $23,08 \pm 5,84$ & 11 & $21,15 \pm 5,66$ \\
\hline
\end{tabular}

повідно), психоемоційні та фізіологічні фактори зустрічались дещо рідше (по $(76,19 \pm 6,57)$ \%). У жінок переважали фізіологічні та психоемоційні фактори (по $(100,00 \pm 0,00) \%)$. Соціально-психологічні та інформаційні фактори спостерігалися рідше - відповідно у $(73,08 \pm 6,15) \%$ та у $(53,85 \pm 6,91) \%$ жінок.

Через 12 місяців у чоловіків переважали інформаційні $(80,95 \pm 6,06) \%$ та соціально-психологічні фактори $(76,19 \pm 6,57) \%$; рідше у чоловіків зустрічались психоемоційні та фізіологічні фактори $((57,14 \pm 7,64) \%$ та $(50,00 \pm 7,72) \%$ відповідно). У жінок достовірно частіше реєструвалися психоемоційні $(73,08 \pm 6,15) \%$, соціально-психологічні $(67,31 \pm 6,51) \%$ та фізіологічні $(63,46 \pm 6,68) \%$ фактори; дещо рідше спостерігались інформаційні фактори - $(36,54 \pm 6,68) \%$.

Через 24 місяці у чоловіків переважали соціально-психологічні фактори $(88,10 \pm 5,00) \%$, інформаційні фактори спостерігались у $(50,00 \pm 7,72) \%$, психоемоційні у $(40,48 \pm 7,57) \%$, фізіологічні - у $(26,19 \pm 6,78) \%$ обстежених. У жінок достовірно частіше відзначалися психоемоційні та соціально-психологічні фактори (відповідно $(78,85 \pm 5,66) \%$ та $(67,31 \pm 6,51)) \%$; фізіологічні та інформаційні фактори зустрічались рідше $((36,54 \pm 6,68) \%$ та $(19,23 \pm$ 5,47) \% відповідно).

На момент обстеження спостерігалось достовірне зниження усіх стресогенних чинників як у чоловіків, так і у жінок. Так, у чоловіків інформаційні та психоемоційні фактори спостерігались у $((26,19 \pm 6,78) \%$, соціально-психологічні та фізіологічні фактори зустрічались рідше - у $(16,67 \pm$ $5,75) \%$. У жінок достовірно частіше відзначалися психоемоційні $(36,54 \pm 6,68)$ \%, соціально-психоло- гічні $(75,61 \pm 6,71)$ \% та фізіологічні фактори $(23,08 \pm$ $5,84) \%$; рідше спостерігався інформаційний фактор - $(21,15 \pm 5,66) \%$.

Таким чином, загальна оцінка стресогенних факторів у I групі ВПО відображає наявність впливу різноманітних чинників психічної травматизації одночасно в різному ступені значущості та їх динаміку в часі, що відображає зменшення значущості стресогенних факторів у повсякденному житті.

У II групи групі обстежених також була проведена оцінка стресогенних факторів, які пацієнти розцінювали як психотравмуючі.

Оцінка факторів психічної травматизації у ВПО II групи представлена у таблиці 2.

Ретроспективна оцінка ФПт під час перебування обстежених у зоні АТО свідчить, що як у чоловіків, так і у жінок переважали фізіологічні $((88,89 \pm 6,05) \%$ i $(100,00 \pm 0,00) \%$ відповідно) та психоемоційні фактори $((96,30 \pm 3,63) \%$ і $(100,00 \pm$ 0,003) \%, відповідно), соціально-психологічні та інформаційні фактори зустрічались дещо рідше (у чоловіків $(62,96 \pm 9,29) \%$ і $(66,67 \pm 9,07) \%$; у жінок $(78,05 \pm 6,46) \% \mathrm{i}(75,61 \pm 6,71) \%$.)

Через 12 місяців у жінок достовірно частіше реєструвалися психоемоційні $(87,80 \pm 5,11) \%$ та соціально-психологічні $(82,93 \pm 5,88)$ \% фактори, фізіологічні та інформаційні ФПТ зустрічалися рідше

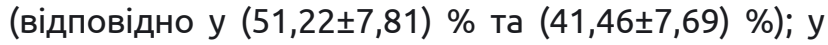
чоловіків переважали інформаційні ФПТ $(85,19 \pm$ $6,84) \%$ та психоемоційні $(77,78 \pm 8,00) \%$ ФПТ, рідше зустрічались соціально-психологічні $(51,85 \pm 9,62) \%$ та фізіологічні $(48,15 \pm 9,62) \%$ ФПТ.

Через 24 місяці у жінок достовірно частіше відзначалися соціально-психологічні $(85,37 \pm 5,52) \%$ та психоемоційні $(82,93 \pm 5,88)$ \% ФПТ, рідше спо- 
Огляди літератури, оригінальні дослідження, погляд на проблему, випадок з практики, короткі повідомлення Таблиця 2. Характеристика факторів психічної травматизації у обстежених внутрішньо переміщених осіб II групи (групи ризику)

\begin{tabular}{|c|c|c|c|c|c|c|c|c|c|}
\hline \multirow{2}{*}{\multicolumn{2}{|c|}{$\begin{array}{c}\text { Фактор психічної трав- } \\
\text { матизації }\end{array}$}} & \multicolumn{2}{|c|}{$\begin{array}{l}\text { Фізіологічний } \\
\text { фактор }\end{array}$} & \multicolumn{2}{|c|}{$\begin{array}{c}\text { Психоемоційний } \\
\text { фактор }\end{array}$} & \multicolumn{2}{|c|}{$\begin{array}{c}\text { Соціально-психологіч- } \\
\text { ний фактор }\end{array}$} & \multicolumn{2}{|c|}{$\begin{array}{c}\text { Інформаційний } \\
\text { фактор }\end{array}$} \\
\hline & & $n$ & $\% \pm m$ \% & $n$ & $\% \pm m \%$ & $n$ & $\% \pm m$ \% & $n$ & $\% \pm m \%$ \\
\hline \multirow{2}{*}{$\begin{array}{c}\text { Під час пере- } \\
\text { бування у } \\
\text { зоні АТО }\end{array}$} & $\begin{array}{l}\text { чоловіки } \\
(n=27)\end{array}$ & 24 & $88,89 \pm 6,05$ & 26 & $96,30 \pm 3,63$ & 17 & $62,96 \pm 9,29$ & 18 & $66,67 \pm 9,07$ \\
\hline & $\begin{array}{l}\text { жінки } \\
(\mathrm{n}=41)\end{array}$ & 41 & $100,00 \pm 0,00$ & 41 & $100,00 \pm 0,00$ & 32 & $78,05 \pm 6,46$ & 31 & $75,61 \pm 6,71$ \\
\hline \multirow[t]{2}{*}{$\begin{array}{c}\text { Через } \\
12 \text { місяців }\end{array}$} & $\begin{array}{l}\text { чоловіки } \\
(\mathrm{n}=27)\end{array}$ & 13 & $48,15 \pm 9,62$ & 21 & $77,78 \pm 8,00$ & 14 & $51,85 \pm 9,62$ & 23 & $85,19 \pm 6,84$ \\
\hline & $\begin{array}{l}\text { жінки } \\
(n=41)\end{array}$ & 21 & $51,22 \pm 7,81$ & 36 & $87,80 \pm 5,11$ & 34 & $82,93 \pm 5,88$ & 17 & $41,46 \pm 7,69$ \\
\hline \multirow[t]{2}{*}{$\begin{array}{c}\text { Через } 24 \\
\text { місяці }\end{array}$} & $\begin{array}{l}\text { чоловіки } \\
(\mathrm{n}=27)\end{array}$ & 10 & $37,04 \pm 9,29$ & 12 & $44,44 \pm 9,56$ & 17 & $62,96 \pm 9,29$ & 12 & $44,44 \pm 9,56$ \\
\hline & $\begin{array}{l}\text { жінки } \\
(\mathrm{n}=41)\end{array}$ & 14 & $34,15 \pm 7,41$ & 34 & $82,93 \pm 5,88$ & 35 & $85,37 \pm 5,52$ & 8 & $19,51 \pm 6,19$ \\
\hline \multirow[t]{2}{*}{$\begin{array}{c}\text { Під час } \\
\text { обстеження }\end{array}$} & $\begin{array}{l}\text { чоловіки } \\
(\mathrm{n}=27)\end{array}$ & 10 & $37,04 \pm 9,29$ & 12 & $44,44 \pm 9,56$ & 19 & $70,37 \pm 8,79$ & 14 & $51,85 \pm 9,62$ \\
\hline & $\begin{array}{l}\text { жінки } \\
(\mathrm{n}=41)\end{array}$ & 16 & $39,02 \pm 7,62$ & 16 & $39,02 \pm 7,62$ & 31 & $75,61 \pm 6,71$ & 12 & $29,27 \pm 7,11$ \\
\hline
\end{tabular}

стерігались фізіологічні $(34,15 \pm 7,41) \%$ та інформаційні $(19,51 \pm 6,19)$ \% фактори. У чоловіків переважали соціально-психологічні, психоемоційні та інформаційні ФПТ $((62,96 \pm 9,29) \%,(44,44 \pm 9,56) \%$ та $(44,44 \pm 9,56) \%)$ відповідно; дещо рідше зустрічались фізіологічні фактори $((34,15 \pm 7,41) \%)$.

На момент обстеження як у жінок, так і в чоловіків достовірно частіше відзначалися соціальнопсихологічні ФПТ (відповідно $(75,61 \pm 6,71) \%$ та $(70,37 \pm 8,79)$ \%). Рідше у жінок зустрічались фізіологічні та психоемоційні фактори - по (39,02士 $7,62)$ \% відповідно, інформаційні фактори - $(29,27 \pm$ $7,11) \%$. У чоловіків рідше зустрічались інформа-

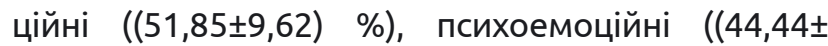
$9,56) \%)$ та фізіологічні фактори $((37,04 \pm 9,29) \%)$.

Отримані результати оцінки ФПТ в групі ризику свідчать про їх психокомплексність та динаміку в часі. При оцінці ФПТ у ІІ групі ВПО встановлено, що на час обстеження у них залишаються актуально значущими як у жінок, так і у чоловіків, соціально-психологічні ФПт (відповідно $(75,61 \pm$ $6,71) \%$ та $(70,37 \pm 8,79) \%)$. Саме високий рівень значущості ФПТ можна розцінювати як фактор ризику виникнення психічних розладів.

Оцінка факторів психічної травматизації у ВПО III групи представлена у таблиці 3.

Таблиця 3. Характеристика факторів психічної травматизації у обстежених внутрішньо переміщених осіб III групи (пацієнтів з психічними розладами)

\begin{tabular}{|c|c|c|c|c|c|c|c|c|c|}
\hline \multirow{2}{*}{\multicolumn{2}{|c|}{$\begin{array}{c}\text { Фактор психічної травма- } \\
\text { тизації }\end{array}$}} & \multicolumn{2}{|c|}{$\begin{array}{c}\text { Фізіологічний } \\
\text { фактор }\end{array}$} & \multicolumn{2}{|c|}{$\begin{array}{c}\text { Психоемоційний } \\
\text { фактор }\end{array}$} & \multicolumn{2}{|c|}{$\begin{array}{c}\text { Соціально-психоло- } \\
\text { гічний фактор }\end{array}$} & \multicolumn{2}{|c|}{$\begin{array}{c}\text { Інформаційний } \\
\text { фактор }\end{array}$} \\
\hline & & $n$ & $\% \pm \mathrm{m} \%$ & $n$ & $\% \pm m \%$ & $n$ & $\% \pm m$ \% & $n$ & $\% \pm m \%$ \\
\hline \multirow{2}{*}{$\begin{array}{c}\text { Під час пере- } \\
\text { бування у } \\
\text { зоні АТО }\end{array}$} & $\begin{array}{c}\text { чоловіки } \\
(n=14)\end{array}$ & 312 & $85,71 \pm 9,35$ & 13 & $92,86 \pm 6,88$ & 9 & $64,29 \pm 12,81$ & 12 & $85,71 \pm 9,35$ \\
\hline & $\begin{array}{l}\text { жінки } \\
(\mathrm{n}=37)\end{array}$ & 435 & $94,59 \pm 3,72$ & 37 & $100,00 \pm 0,00$ & 17 & $45,95 \pm 8,19$ & 18 & $48,65 \pm 8,22$ \\
\hline \multirow[t]{2}{*}{$\begin{array}{c}\text { Через } \\
12 \text { місяців }\end{array}$} & $\begin{array}{c}\text { чоловіки } \\
(n=14)\end{array}$ & 55 & $35,71 \pm 12,81$ & 9 & $64,29 \pm 12,81$ & 11 & $78,57 \pm 10,97$ & 12 & $85,71 \pm 9,35$ \\
\hline & $\begin{array}{l}\text { жінки } \\
(\mathrm{n}=37) \\
\end{array}$ & 110 & $27,03 \pm 7,30$ & 34 & $91,89 \pm 4,49$ & 31 & $83,78 \pm 6,06$ & 11 & $29,73 \pm 7,51$ \\
\hline \multirow[t]{2}{*}{$\begin{array}{l}\text { Через } 24 \\
\text { місяці }\end{array}$} & $\begin{array}{c}\text { чоловіки } \\
(n=14)\end{array}$ & 55 & $35,71 \pm 12,81$ & 12 & $85,71 \pm 9,35$ & 9 & $64,29 \pm 12,81$ & 6 & $42,86 \pm 13,23$ \\
\hline & $\begin{array}{l}\text { жінки } \\
(\mathrm{n}=37)\end{array}$ & 99 & $24,32 \pm 7,05$ & 27 & $72,97 \pm 7,30$ & 29 & $78,38 \pm 6,77$ & 11 & $29,73 \pm 7,51$ \\
\hline \multirow[t]{2}{*}{$\begin{array}{c}\text { Під час } \\
\text { обстеження }\end{array}$} & $\begin{array}{c}\text { чоловіки } \\
(n=14)\end{array}$ & 3 & $21,43 \pm 10,97$ & 12 & $85,71 \pm 9,35$ & 10 & $71,43 \pm 12,07$ & 4 & $28,57 \pm 12,07$ \\
\hline & $\begin{array}{l}\text { жінки } \\
(n=37)\end{array}$ & 99 & $24,32 \pm 7,05$ & 24 & $64,86 \pm 7,85$ & 31 & $83,78 \pm 6,06$ & 8 & $27,03 \pm 7,30$ \\
\hline
\end{tabular}


Огляди літератури, оригінальні дослідження, погляд на проблему, випадок з практики, короткі повідомлення

Оцінка ФПТ відображає певну їх динаміку. Так, всі обстежені констатували у себе сукупність фізіологічних, психоемоційних, соціально-психологічних, інформаційних факторів психічної травматизації, що вони пов'язували із перенесеною сильною стресовою ситуацією під час військової агресії, до якої ніхто з них не був готовий.

Ретроспективна оцінка ФПТ під час перебування обстежених у зоні АТО свідчить, що у $(85,71 \pm 9,35)$ \% чоловіків та $(94,59 \pm 3,72) \%$ жінок переважали фізіологічні фактори. Також у значної кількості жінок та чоловіків часто виявлялись психоемоційні фактори - відповідно $(100,00 \pm 0,00) \%$ та $(92,86 \pm 6,88) \%$. Інформаційні фактори частіше спостерігалися у чоловіків $-(85,71 \pm 9,35) \%$, у жінок реєструвалися рідше - $(48,65 \pm 8,22) \%$ випадків. Соціально-психологічні фактори спостерігалися у $(64,29 \pm 12,81) \%$ чоловіків та у $(45,95 \pm 8,19) \%$ жінок.

Через 12 місяців у жінок достовірно частіше реєструвалися психоемоційні $(91,89 \pm 4,49) \%$ та соціально-психологічні $(83,78 \pm 6,06) \%$ ФПТ; у чоловіків переважали інформаційні $(85,71 \pm 9,35)$ \% та соціально-психологічні ФПТ $(78,57 \pm 10,97) \%$.

Через 24 місяці у жінок достовірно частіше відзначалися соціально-психологічні $(78,38 \pm 6,77) \%$ та психоемоційні $(72,97 \pm 7,30) \%$ ФПТ, у чоловіків також переважали психоемоційні $(85,71 \pm 9,35) \%$ та соціально-психологічні $(64,29 \pm 12,81) \%$ ФПТ.

На момент обстеження у жінок та чоловіків достовірно частіше реєструвалися соціально-психологічні ФПТ $(83,78 \pm 6,06) \%$ та $(71,43 \pm 12,07) \%$; психоемоційні $(64,86 \pm 7,85) \%$ та $(85,71 \pm 9,35) \%$ та інформаційні ФПТ $(21,62 \pm 6,7) \%$.

При визначенні ФПТ також оцінювалась стресостійкість та соціальна адаптація за допомогою Методики визначення стресостійкості та соціальної адаптації Т. Холмса і Р. Раге (Т. Holmes and R. Rahe, 1967), яка дозволяє оцінити актуальний рівень стресу протягом останнього року. За отриманими результатами було встановлено, що в групі здорових ВПО переважали особи з середнім рівнем опірності стресу - 55,32 \%, у $28,73 \%$ осіб був встановлений низький рівень опірності стресу та у $15,96 \%$ - високий. У групі ризику у $44,12 \%$ осіб визначалась низька опірність стресовим факторам, у 52,94 \% - середня та у 2,94 \% висока. У обстежених ВПО з психічними розладами у 76,47 \% був встановлений низький рівень опірності стресам, у 21,57\% - середній та у $1,96 \%$ високий (рис. 1).

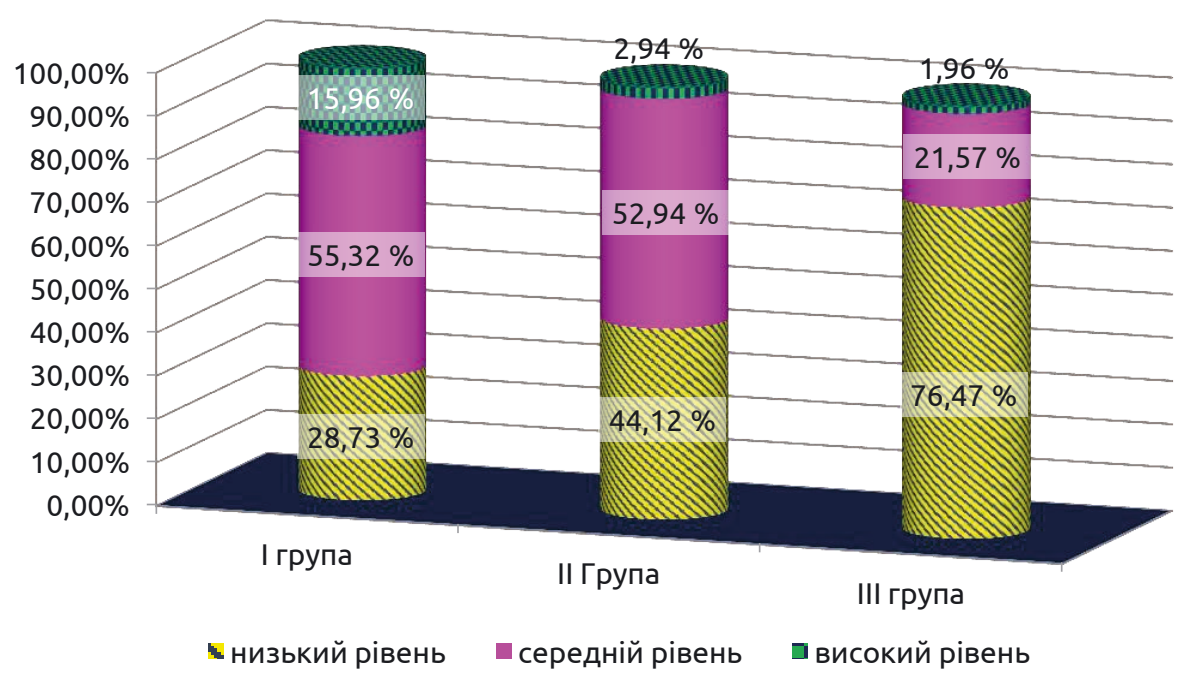

Рис. 1. Рівень опірності стресовим подіям у внутрішньо переміщених осіб (за методикою визначення стресостійкості та соціальної адаптації Т. Холмса і Р. Раге).

Статистичний аналіз показав, що високий рівень опірності стресу відрізняв здорових від хворих та осіб з групи ризику (ДК=9,11, Мl=0,64, p<0,006 та ДК=7,34, Ml=0,48, $p<0,004$ відповідно), у яких був більш виражений низький рівень опірності стресу (ДК=4,25, Ml=1,02, $p<0,0001$ та ДК=1,86, $\mathrm{Ml}=0,14, \mathrm{p}<0,01$ відповідно). Також було визначено, що осіб із середнім рівнем опірності стресовим факторам було більше серед здорових та в групі ризику, ніж серед пацієнтів (ДК=4,091, MI=0,69, $\mathrm{p}<0,0001$ та ДК=3,90, MI=0,61, $\mathrm{p}<0,0003$ відповідно).

Подальший детальний якісний аналіз результатів дозволив проранжувати власне стресові події, що відбувалися за рік, за вираженістю (табл. 4).

Як свідчать наведені дані, найпоширенішими стресовими подіями, що реєструвалися в групі здорових ВПО, були фактори, пов'язані зі зміною фінансового становища, умов життя та місця 
Огляди літератури, оригінальні дослідження, погляд на проблему, випадок з практики, короткі повідомлення Таблиця 4. Вираженість стресових подій у внутрішньо переміщених осіб

\begin{tabular}{|c|c|c|c|}
\hline \multirow{2}{*}{ Найменування стресових подій } & І група & II група & III група \\
\hline & \multicolumn{3}{|c|}{ рангове місце } \\
\hline Зміна звичок, пов'язаних зі сном, порушення сну & 19 & 11 & 1 \\
\hline Зміна звичок, пов'язаних з харчуванням (кількість їжі, дієта) & 16 & 13 & 2 \\
\hline Травма або хвороба & 18 & 12 & 3 \\
\hline Зміна в стані здоров'я членів сім'ї & 17 & 14 & 4 \\
\hline Смерть близького члена сім'ї & 11 & 15,5 & 5 \\
\hline Проблеми з родичами чоловіка (дружини) & 12,5 & 15,5 & 6 \\
\hline Роз'їзд подружжя (без оформлення розлучення), розрив з партнером & 12,5 & 22 & 7 \\
\hline Звільнення з роботи & 14 & 18 & 8 \\
\hline Видатне особисте досягнення, успіх & 18 & 21 & 9 \\
\hline Сексуальні проблеми & 20 & 19 & 10 \\
\hline Зміна фінансового становища & 1 & 9 & 11 \\
\hline Розлучення & 15 & 10 & 12 \\
\hline Зміна умов життя & 2 & 4 & 13 \\
\hline Відмова від якихось індивідуальних звичок, зміна стереотипів & 3 & 6,5 & 14,5 \\
\hline Зміна профорієнтації, зміна місця роботи & 4 & 8 & 14,5 \\
\hline Зміна місця проживання & 5,5 & 3 & 16 \\
\hline Смерть близького друга & 5,5 & 17 & 17 \\
\hline $\begin{array}{l}\text { Зміна числа осіб, що живуть разом (членів сім'ї, характеру і частоти зустрі- } \\
\text { чей з іншими членами сім'ї) }\end{array}$ & 7 & 2 & 18 \\
\hline Відпустка & 21 & 23 & 19 \\
\hline Зміна умов або годин роботи & 8 & 1 & 20 \\
\hline Зміна звичок, пов'язаних з проведенням дозвілля чи відпустки & 10 & 5 & 21 \\
\hline Зміна соціальної активності & 9 & 6,5 & 22 \\
\hline Позика для покупки не крупних речей (наприклад, телевізора) & 22 & 20 & 23 \\
\hline
\end{tabular}

проживання, місця роботи чи професії, смертю близького друга тощо. В групі ризику переважали стресові події, пов'язані зі зміною умов роботи, місця проживання та кількості осіб, що проживають разом, а також зі зміною звичок, пов'язаних із проведенням дозвілля чи відпустки. У групі пацієнтів з психічними розладами частіше спостерігалися: порушення сну, зміна звичок, пов'язаних із харчуванням, травми чи хвороби, зміни в стані здоров'я або смерть членів сім'ї, проблеми з родичами, подружжям, розрив стосунків з партнером, звільнення з роботи.

Висновки. 1. Загальна оцінка впливу стресогенних чинників на ВПО свідчить про їх поєднану дію, різний ступінь патогенності та динаміки у часі. Під час перебування в зоні АТО усі компоненти стресу (фізіологічні, психоемоційні, соціальнопсихологічні та інформаційні) характеризувалися високим ступенем патогенності, з плином часу значущість деяких чинників зменшувалась, а деяких - зростала.
2. У групі здорових ВПО зареєстровано зниження актуальності усіх складових стресогенного впливу; в групі ризику актуальність не втрачали соціально-психологічні ФПТ $((75,61 \pm 6,71) \%$ у жінок та $(70,37 \pm 8,79)$ \% у чоловіків); у пацієнтів 3 психічними розладами виявлена висока значущість соціально-психологічних $((83,78 \pm 6,06) \%$ у жінок та $(71,43 \pm 12,07)$ \% у чоловіків); психоемоційних $((64,86 \pm 7,85) \%$ у жінок та $(85,71 \pm 9,35) \%$ у чоловіків) та інформаційних $((27,03 \pm 7,30) \%$ у жінок та $(28,57 \pm 12,07)$ \% у чоловіків).

3. Встановлено переважання високого та середнього рівнів опірності стресовим подіям у здорових (ДК=9,11 та ДК=4,09 відповідно), середнього рівня $(Д К=3,90)$ в групі ризику та низького рівня опірності стресовим подіям (ДК=4,25) у обстежених з психічними розладами. В ґенезі опірності стресу для здорових та групи ризику провідну роль відіграють соціально-стресові чинники, а для пацієнтів з психічними розладами - чинники власного здоров'я. 
Огляди літератури, оригінальні дослідження, погляд на проблему, випадок з практики, короткі повідомлення ЛІТЕРАТУРА

1. Рингач Н. О. Міграція та громадське здоров'я: міжнародне бачення і Українські реалії у контексті національної безпеки / Н. О. Рингач // Науковий часопис Академії національної безпеки. - 2018. - Випуск 3-4 (1920). - С. 111-126.

2. Витковская Г. С. Вынужденная миграция и мигрантофобия / Г. С. Витковская : Нетерпимость в России, старые и новые фобии. - М. : Московский центр Карнеги, 2009. - С. 151-191.

3. Надрага В. Проблеми вимушеної внутрішньої міграції населення в контексті концепції «суспільства ризику» / В. Надрага // Український соціум. - 2015. - №1 (52). - С. 134-141.

4. Смаль В. Внутрішньо переміщені особи: соціальна та економічна інтеграція в приймаючих громадах (за матеріалами Вінницької, Запорізької, Івано-Франківської та Полтавської областей) / В. Смаль, О. Позняк. Проект ПРОМІС, 2016. - 93 с.

5. Маслова Т. Ф. Социальное самочувствие вынужденных переселенцев / Т. Ф. Маслова // Социс. - 2013. № 3. - С. 103-107.

6. Попова О. А. Классификационный анализ вынужденной внутренней миграции в Украине / О. А. По-

\section{REFERENCES}

1. Rynhach, N.O. (2018). Mihratsiia ta hromadske zdorovia: mizhnarodne bachennia i Ukrainski realii u konteksti natsionalnoi bezpeky [Migration and public health: an international vision and Ukrainian realities in the context of national security]. Naukovyi chasopys Akademii natsionalnoi bezpeky - Scientific Journal of the Academy of National Safety, 3-4 (19-20), 111-126 [in Ukrainian].

2. Vitkovskaya, G.S. (2009). Vynuzhdennaya migratsiya i migrantofobiya [Forced migration and migrantophobia]. Neterpimost v Rossii staryye i novyye fobii. Moscow: Moskovskiy tsentr Karnegi [in Russian].

3. Nadraha, V. (2015). Problemy vymushenoi vnutrishnoi mihratsii naselennia v konteksti kontseptsii "suspilstva ryzyku" [Problems of forced internal migration of the population in the context of the concept of "risk society"]. Ukrainskyi sotsium - Ukrainian Society, 1 (52), 134-141 [in Ukrainian].

4. Smal, V. (2016). Vnutrishno peremishcheni osoby: sotsialna ta ekonomichna intehratsiia $v$ pryimaiuchykh hromadakh (Za materialamy Vinnytskoi, Zaporizkoi, IvanoFrankivskoi ta Poltavskoi oblastei) [Internally displaced persons: the social and economic integration in host communities (Source Vinnytsia, Zaporizhia, Ivano-Frankivsk and Poltava)]. Proekt PROMIS [in Ukrainian].

5. Maslova, T.F. (2013). Sotsialnoye samochuvstviye vynuzhdennykh pereselentsev [Social well-being of internally displaced persons]. Sotsis, 3, 103-107 [in Ukrainian].

6. Popova, O.A. (2017). Klassifikatsionnyy analiz vynuzhdennoy vnutrenney migratsii v Ukraine [Classification analysis of forced internal migration in Ukraine]. Naukovoteoretichnyi almanakh "Hrani" - Scientific and Theoretical Almanac "Edges", 20, 7 (147), 65-71 [in Ukrainian].

пова // Науково-теоретичний альманах «Грані». - 2017. T. 20, № 7 (147). - С. 65-71.

7. Михайлов Б. В. Розлади психіки і поведінки екстремально психологічного походження / Б. В. Михайлов // Психічне здоров'я. - 2015. - № 2 (47). - С. 9-18.

8. Ощепкова В. С. Особенности социально-психологической адаптации вынужденных мигрантов из Украины / В. С. Ощепкова // Гуманитарные научные исследования. -2017 . - № 12.

9. Герасименко Л. О. Психосоціальна дезадаптація (сучасні концептуальні моделі) / Л. О. Герасименко // Укр. вісн. психоневрології. - 2018. - № 1. - С. 62-65.

10. Войналович І. А. Вимушені переселенці: зарубіжний досвід, стан та реалізація їх прав в Україні / I. А. Войналович, М. О. Кримова, Л. В. Щетініна // Соціально-трудові відносини: теорія та практика . - 2014. - № 2. - С. 250-257.

11. Закіров М. Деякі аспекти розв'язання проблем внутрішньо переміщених осіб / М. Закіров // Резонанс. - 2016. - № 39. - С. 5-10.

12. Литература: Практическая психодиагностика. Методики и тесты : учебное пособие / Д. Я. Райгородский (редактор-составитель). - Самара : Издательский Дом «БАХРАХ-М», 2001. - 672 с.

7. Mykhailov, B.V. (2015). Rozlady psykhiky i povedinky ekstremalno psykholohichnoho pokhodzhennia [Disorders of the psyche and behavior of extreme psychological origin]. Psykhichne zdorovia - Mental Health, 2 (47), 9-18 [in Ukrainian].

8. Oshchepkova, V.S. (2017). Osobennosti sotsialnopsikhologicheskoy adaptatsii vynuzhdennykh migrantov iz Ukrainy [Features of socio-psychological adaptation of forced migrants from Ukraine]. Gumanitarnyye nauchnyye issledovaniya - Humanitarian Scientific Researches, 12 [in Ukrainian].

9. Herasymenko, L.O. (2018). Psykhosotsialna dezadaptatsiia (suchasni kontseptualni modeli) [Psychosocial maladaptation (modern conceptual models)]. Ukr. visn. Psykhonevrolohii-Ukrainian Bulletin of Psychoneurology, 1, 62-65 [in Ukrainian].

10. Voinalovych, I.A., Krymova, M.O., \& Shchetinina, L.V. (2014). Vymusheni pereselentsi: zarubizhnyi dosvid, stan ta realizatsiia yikh prav v Ukraini [Forced migrants: foreign experience, status and realization of their rights in Ukraine]. Sotsialno-trudovi vidnosyny: teoriia ta praktyka Social and Labour Relationships, 2, 250-257 [in Ukrainian].

11. Zakirov, M. (2016). Deiaki aspekty rozviazannia problem vnutrishnoperemishchenykh osib [Some aspects of solving displaced persons]. Rezonans, 39, 5-10 [in Ukrainian].

12. (2001). Literatura: Prakticheskaya psikhodiagnostika. Metodiki i testy. Uchebnoye posobiye [Literature: Practical psychodiagnostics. Methods and tests. Textbook]. Raygorodskiy D.Ya. (Ed.). Samara: Izdatelskiy Dom "BAKHRAKH-M" [in Russian]. 
Огляди літератури, оригінальні дослідження, погляд на проблему, випадок з практики, короткі повідомлення ФАКТОРЫ ПСИХИЧЕСКОЙ ТРАВМАТИЗАЦИИ У ВНУТРЕННЕ ПЕРЕМЕЩЕННЫХ ЛИЦ: ИХ СТРУКТУРА И ДИНАМИКА ВО ВРЕМЕНИ

\author{
○Н. А. Марута, Т. В. Панько, Г. Ю. Каленская, С. П. Колядко, И. А. Явдак, С. О. Волкова

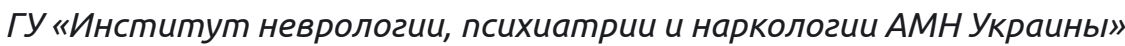

PEЗЮМЕ. Сегодня Украина занимает девятое место в мире по количеству внутренне перемещенных лиц. Масштабные вынужденные внутренние миграции последних лет не могли не отразиться на состоянии здоровья как определенной социальной группы, так и на состоянии здоровья населения в целом.

Цель - изучение факторов психической травматизации, их динамики во времени и влияния на состояние психического здоровья, определение стрессоустойчивости и социальной адаптации у ВПО.

Материал и методы. Методы обследования включали клинико-психопатологический с оценкой факторов психической травматизации, методика определения стрессоустойчивости и социальной адаптации Т. Холмса и P. Pare (T. Holmes and R. Rahe, 1967) для оценки актуального уровня стресса в течение последнего года и статистические методы.

Исследование проводилось в ГУ «Институт неврологии, психиатрии и наркологии НАМН Украины» в отделе пограничной психиатрии. Всего было обследовано 213 ВПО. Все обследованные были поделены на 3 группы: в І группу вошли 94 ВПО из общей популяции, у которых не было выявлено психических расстройств (условно здоровые), во II группу (группу риска) вошли 68 человек, у которых были определены отдельные психические симптомы, не достигающие клинического уровня, и в III группу вошел 51 человек, обратившийся за медицинской помощью и имеющий психические расстройства.

Результаты. У всех обследованных была проведена оценка стрессогенных факторов, включавшая физиологические, психоэмоциональные, социально-психологические и информационные факторы и отражающая их динамику во времени. Оценка уровня сопротивляемости показала его отличия у обследованных здоровых, больных и лиц группы риска.

Выводы. Оценка влияния стрессогенных факторов на ВПО свидетельствует об их сочетанном действии, разных степени патогенности и динамике во времени.

КЛЮчЕВЫЕ СЛОВА: факторы психической травматизации; внутренне перемещенные лица.

\title{
FACTORS OF MENTAL TRAUMATIZATION IN INTERNALLY DISPLACED PERSONS: THEIR STRUCTURE AND DYNAMICS IN TIME
}

\author{
@N. O. Maruta, T. V. Panko, G. Yu. Kalenska, S. P. Kolyadko, I. O. Yavdak, S. O. Volkova \\ Institute of Neurology, Psychiatry and Narcology, NAMS of Ukraine
}

SUMMARY. Today, Ukraine ranks ninth in the world in the number of internally displaced persons (IDPs). Large-scale forced internal migration in recent years could not but affect the health status of a particular social group, as well as the health status of the population as a whole.

The aim of the study - to learn the factors of mental trauma, their dynamics over time and the impact on mental health, the determination of stress resistance and social adaptation in HPE.

Material and Methods. Survey methods included clinical psychopathology with assessment of mental trauma factors, T. Holmes and R. Rahe (1967) methods for determining stress tolerance and social adaptation to assess current levels of stress during the last year, and statistical methods.

The study was conducted at the State Institution "Institute of Neurology, Psychiatry and Narcology of the National Academy of Medical Sciences of Ukraine" in the Department of Border Psychiatry. A total of 213 IDPs were surveyed. All of the surveyed were divided into 3 groups: group I included 94 IDPs from the general population who had no identified psychiatric disorders (conditionally healthy), group II (risk group) waxed 68 people who had identified certain psychiatric symptoms that were not clinical level, made up and in group III included 51 people who sought medical help and having mental disorders.

Results. All subjects were evaluated for stress factors, including, physiological, psycho-emotional, socio-psychological and information factors and reflected their dynamics over time. The conducted assessment of the level of resistance showed its differences in the examined healthy, patients and risk groups.

Conclusions. An assessment of the influence of stressful factors on IDP indicates their combined effect, varying degrees of pathogenicity, and dynamics over time.

KEY WORDS: mental trauma factors; internally displaced persons. 